\title{
The terrestrial isopod fauna of the Rinya region IV. Szilonics-puszta
}

\author{
VADKERTI Edit and FARKAS Sándor
}

VADKERTI E. and FARKAS S.: The terrestrial isopod fauna of the Rinya region IV. Szilonics-puszta. Abstract: Isopods of a wetland forest and the surrounding ruderal vegetation were sampled along a line transect by pitfall trapping. The captured 5 species were: Porcellium collicola Verh., Trachelipus ratzeburgi Brandt, T. rathkei Brandt, Armadillidium vulgare Latr. and Hyloniscus riparius Koch.. The number of individuals was much greater than expected. No difference was found between the spatial distribution of the species. T. ratzeburgi was the dominant species in both of the vegetations. The seasonal changes in surface activity, sex ratio and the number of gravid females were also examined.

Keywords: Isopod, Oniscidea, Hyloniscus riparius, Porcellium collicola, Trachelipus ratzeburgi, T. rathkei, Armadillidium vulgare, pitfall trapping, Danube-Drava National Park, wetland, spatial distribution, habitat preference, surface activity, sex ratio, population dynamics.

\section{Introduction}

The Danube-Drava National Park is located in South Transdanubia in Hungary and consists of many islandlike natural reserves. The systematic ecological research of the isopods living in the regions of DDNP began in 1996. One of the 61 sampling sites was located at Szilonicspuszta. The main questions of this study were: (1) which Isopoda species live here, (2) whether there is any habitat preference of the different Isopoda species, and how (3) the surface activity (4) the community structure (5) sex ratio and reproductive characteristics of their populations change in time.

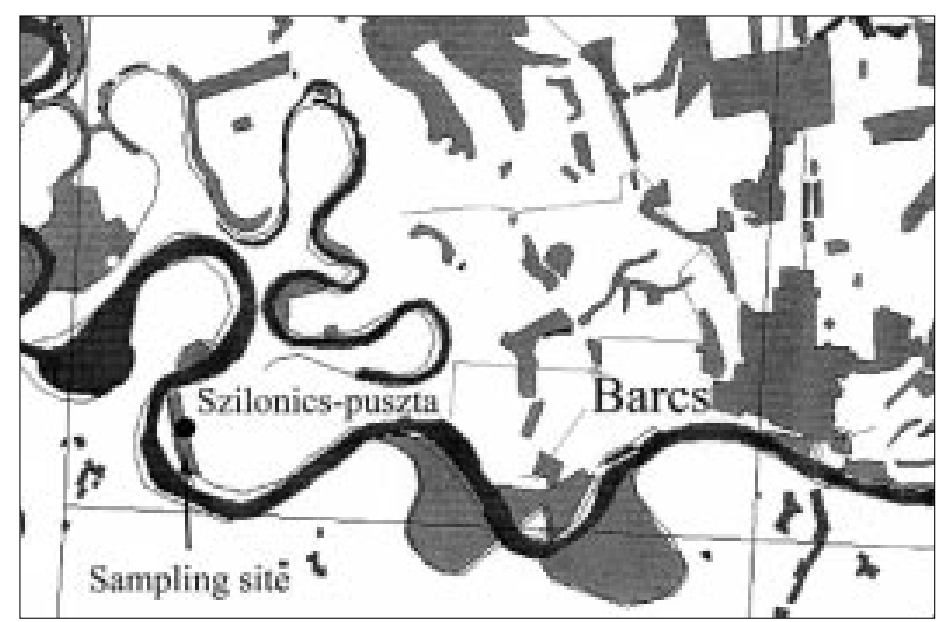

Fig. 1. The location of the sampling site 


\section{Material and methods}

Szilonicspuszta is located $8 \mathrm{~km}$ west of Barcs (Fig. 1). The average temperature of the examined area in July is $21-22^{\circ} \mathrm{C}$ and in the vegetation period (between $1^{\text {st }}$ of April and $30^{\text {th }}$ of September) is $17-18{ }^{\circ} \mathrm{C}$. The annual precipitation is $700 \mathrm{~mm}$.

The studied area consists of two habitat types: a wetland forest and an inundation ruderal vegetation which was a dense Solidago canadensis association. Five pitfall traps were placed in each of them. All of them were set in a 45-meter line transect. The distance between the traps was 5 meters. The transect started inside the forest and perpendicularly crossed the edge, ending in the ruderal vegetation. The leaf litter in the habitats was sparse.

The material was collected between $7^{\text {th }}$ June 1996 and $15^{\text {th }}$ November 1996. In spring the examined area was so wet that the experiment could not be begun until $1^{\text {st }}$ May.

The data were standardized to analyse sesonal changes in surface activity by the equation: $\mathrm{N} / \mathrm{d}^{*} \mathrm{t}_{\mathrm{w}}$, where $\mathrm{N}=$ number of individuals in one sample, $\mathrm{d}=$ number of days between two checkings, and $t_{w}=$ number of working traps. The sex ratio of the species was determined. Males were recognized by the presence of elongate pleopods on the ventral surface of the pleon. Individuals with marsupia were regarded as gravid females irrespective of whether the marsupium was full or empty.

The habitat preference was tested by multivariable statistics (TÓTHMÉRÉSz 1996).

\section{Results and discussion}

(1) The 10 traps caught 5 species: Porcellium collicola Verh., Trachelipus ratzeburgi Brandt, T. rathkei Brandt and Armadillidium vulgare Latr., Hyloniscus riparius Koch (Table 1). Between 1996 and 1998 among others 8 wetland forests and 3 inundation ruderal vegetation were studied (FARKAS 1999). In all of these two kinds of habitats only these 5 species were collected so this result was to be expected. In other habitats the number of species were between 1 and 11 .

Table 1. Number of captured male, gravid and non-gravid female individuals

\begin{tabular}{|c|c|c|c|c|c|c|c|c|c|c|c|c|}
\hline & \multicolumn{3}{|c|}{ Porcellium collicola } & \multicolumn{3}{|c|}{ Trachelipus ratzeburgi } & \multicolumn{3}{|c|}{ Trachelipus rathkei } & \multicolumn{3}{|c|}{ Armadillidium vulgare } \\
\hline & males & ngravid & gravid & males & ngravid & gravid & males & ngravid & gravid & males & ngravid & gravid \\
\hline 06. 07 . & 27 & 76 & 26 & 461 & 666 & 554 & 243 & 198 & 143 & 695 & 1065 & 258 \\
\hline 06. 21 . & 23 & 37 & 74 & 207 & 162 & 80 & 86 & 66 & 127 & 136 & 220 & 154 \\
\hline 07.06. & 67 & 25 & 227 & 270 & 285 & 653 & 121 & 69 & 247 & 162 & 574 & 225 \\
\hline 07. 31 . & 30 & 24 & 425 & 381 & 176 & 878 & 217 & 77 & 302 & 164 & 651 & 180 \\
\hline 08. 19 . & 10 & 30 & 190 & 234 & 458 & 202 & 166 & 222 & 83 & 84 & 342 & 77 \\
\hline 09. 10 . & 71 & 212 & 212 & 434 & 880 & 591 & 157 & 430 & 98 & 96 & 398 & 72 \\
\hline 09. 27. & 43 & 119 & 81 & 83 & 170 & 83 & 39 & 139 & 19 & 15 & 40 & 0 \\
\hline 10. 25 . & 20 & 182 & 0 & 412 & 642 & 61 & 306 & 370 & 0 & 8 & 23 & 0 \\
\hline 11. 15 & 2 & 40 & 0 & 90 & 151 & 5 & 39 & 128 & 0 & 0 & 2 & 0 \\
\hline
\end{tabular}




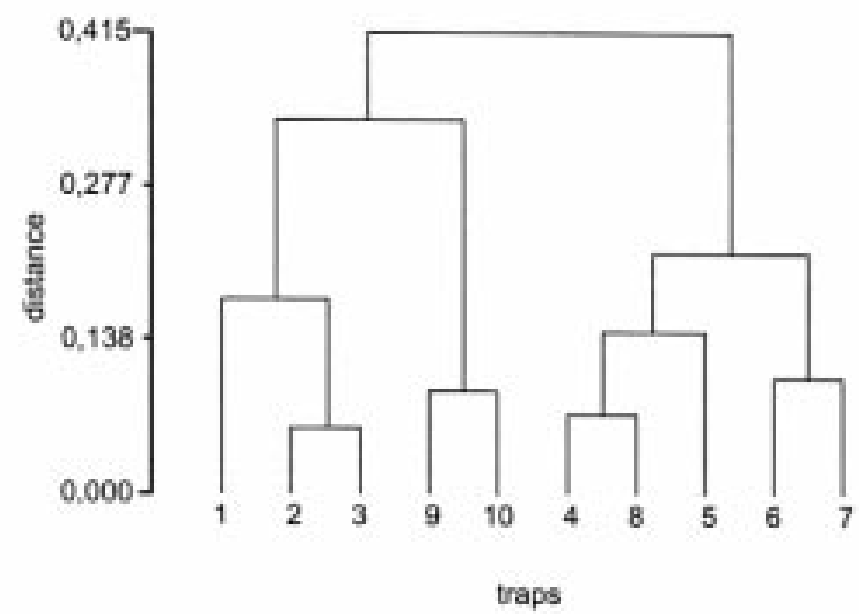

Fig. 2. The similarity dendogram of the 10 traps by the isopod assemblages. Traps situated in wetland forest: 1 - 5; traps situated in inundation ruderal vegetation: 6 - 10 .

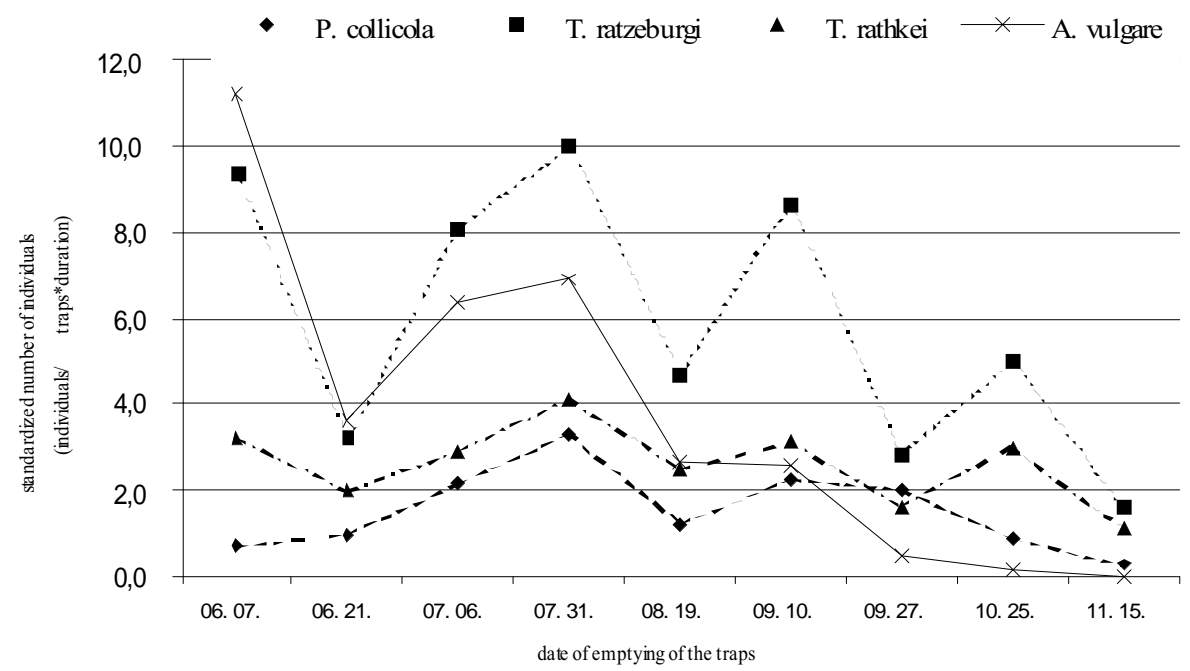

Fig. 3. Seasonal changes in surface activity of the species 
(2) By the results of the cluster analysis of the isopod assemblages cought by the traps there is no habitat preference; the occurrance of the species does not reflect the difference between the two associations (Fig. 2). It is not surprising because $H$. riparius occurs everywhere independently from the type of association where there are moist microhabitats (GRUNER 1966). The other four species occur in all of the habitats in this region (FARKAS 1999).

(3) The total of 21,664 individuals of the 5 species were collected. Comparing these results to other similar long term experiments the number of individuals were 5 to 20 times more. The low number of Hyloniscus riparius (less then 1\%) did not enable a reliable analysis so they were omitted from the statistics. The number of invidiuals was the highest at Szilonicspuszta among the habitats examined in the regions of DDNP. The surface activity of the four species had three peaks (Fig. 3). It may be concluded that the surface activity was the highest at the beginning of the summer. After a decrease at the end of June the activity showed an increasing tendency again. The decrease in the number of trapped animals on $19^{\text {th }}$ August was probably due to a sampling error because the activity of the species was the highest in other sampled areas in this period (FARKAS, 1998a, 1998b).

(4) The temporal pattern of the composition of isopod assemblages did not change during the sampled period (Fig. 4) apart from $A$. vulgare whose participation decreased continuously. T. ratzeburgi was the dominant species in both vegetations; its participation did not drop below $30 \%$.

(5) The seasonal changes in sex ratio of the species (Fig. 5, 6, 7, 8) were different. The amount of gravid females of three species (T. rathkei, T. ratzeburgi, $P$. collicola) showed a similar tendency. The number of gravid females increased rapidly in June, peaked in July and decreased gradually from August. A. vulgare showed a different pattern: it peaked in June with a value at $30 \%$.

MCQUEEEN (1976) reported that temperature is the major factor regulating growth, mortality and reproductive timing of Trachelipus rathkei. He found that $83 \%$ of mated adults produced one brood, and $42 \%$ a second, with some indication that the reproductive rate might be temperature-dependent. High temperature affects the reproductive pattern of isopods (HORNUNG and WARBURG 1993). The mean duration of gravidity were 51.4, 30.7, and 17.6 days at temperatures of 15.6, 21.0 and 26.7 ${ }^{\circ} \mathrm{C}$ (SNIDER and SHADDY 1980). They found that the most favorable temperature was $21^{\circ} \mathrm{C}$, for both breeding and non-breeding females. The number of consecutive broods produced was dependent on initial female weight, the smaller females tending to breed only once (it was also influenced by temperature, since the highest temperature increased the incidence of second and third broods. From the end of May to middle of August 60-93 percent of the females were gravid. In our study the proportion of gravid T. rathkei females was 30-60\% in June and July, and 10-20\% during August and September. The gravid T. ratzeburgi females had a higher peak in July (60\%) and a smaller one in September (20-30\%). The number of nongravid females exceeded the gravids of both species from August. Porcellium collicola has one big, longterm breeding period. The amount of gravid females ranged between 40-90 percent. There were no available data on the population biology of T. ratzeburgi and $P$. collicola to compare these results.

For Armadillidium vulgare growth was more sensitive to changes in food quality than to temperature (HELDEN and HASSALL 1998). At low food quality 30-50\% of the females were gravid while at high food quality this amount was $70-90 \%$. There is a strong selection pressure for juveniles to respond strongly to temperature with respect to growth rates. In the spring and early summer, when they are larger, food availability is more limiting. At Szilonicspuszta the proportion of gravid females was low, 10-30\%.

DANGERFIELD and TELFORD (1994) studied the sex ratio of 5 isopod species. The per- 


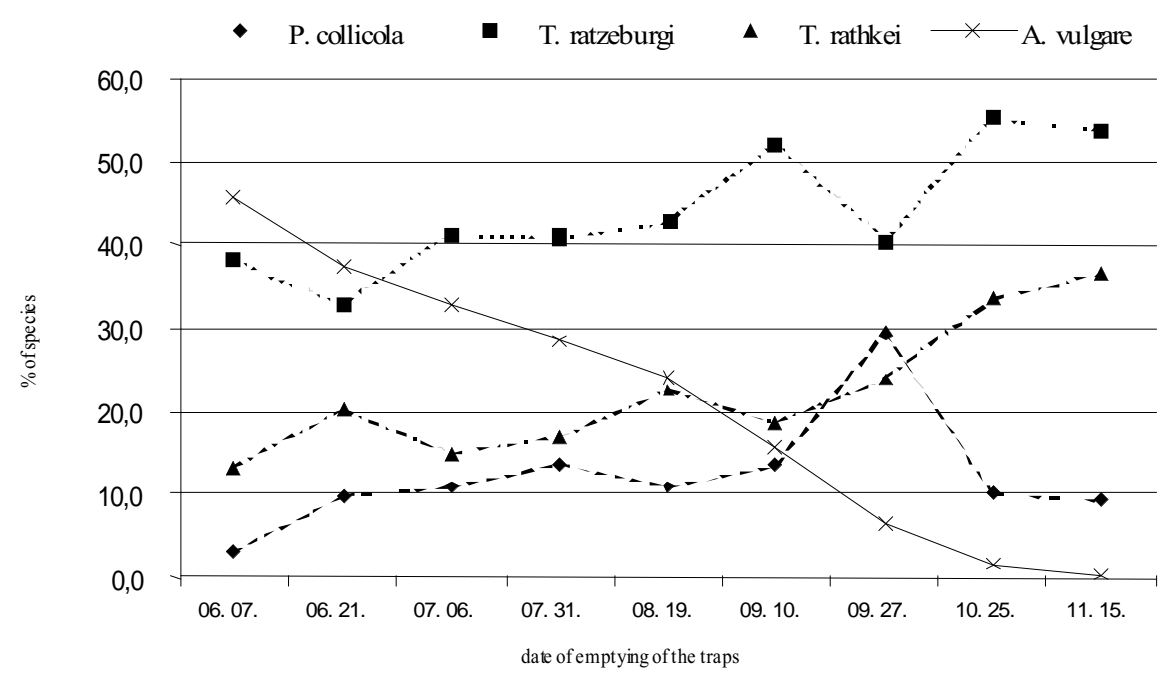

Fig. 4. Temporal changes in the composition of isopod assemblage

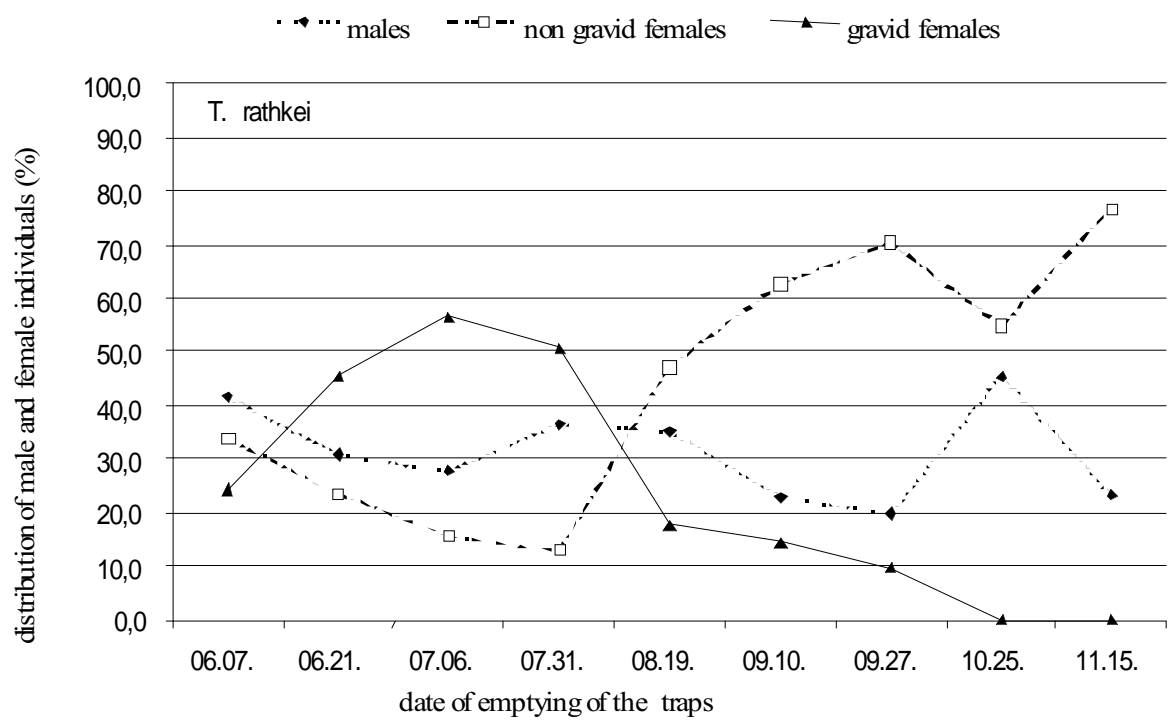

Fig. 5. Seasonal changes in the amount of male, gravid and non-gravid female individuals of $T$. rathkei 


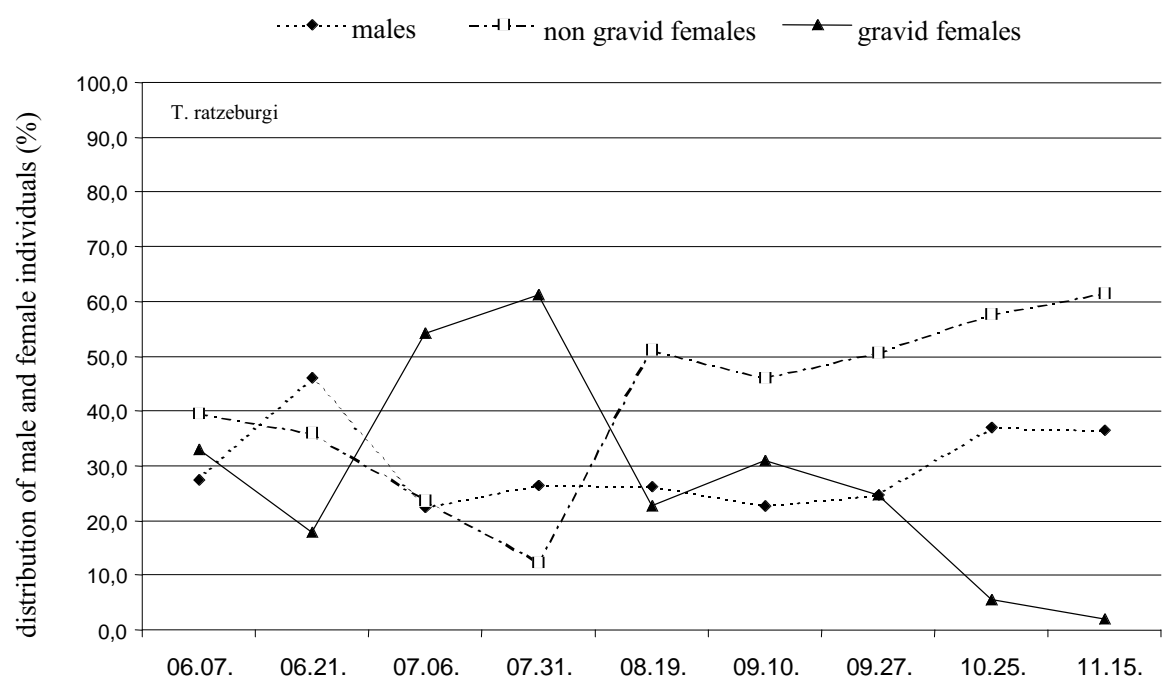

date of emptying of the traps

Fig. 6. Seasonal changes in the amount of male, gravid and non-gravid female individuals of $T$. ratzeburgi

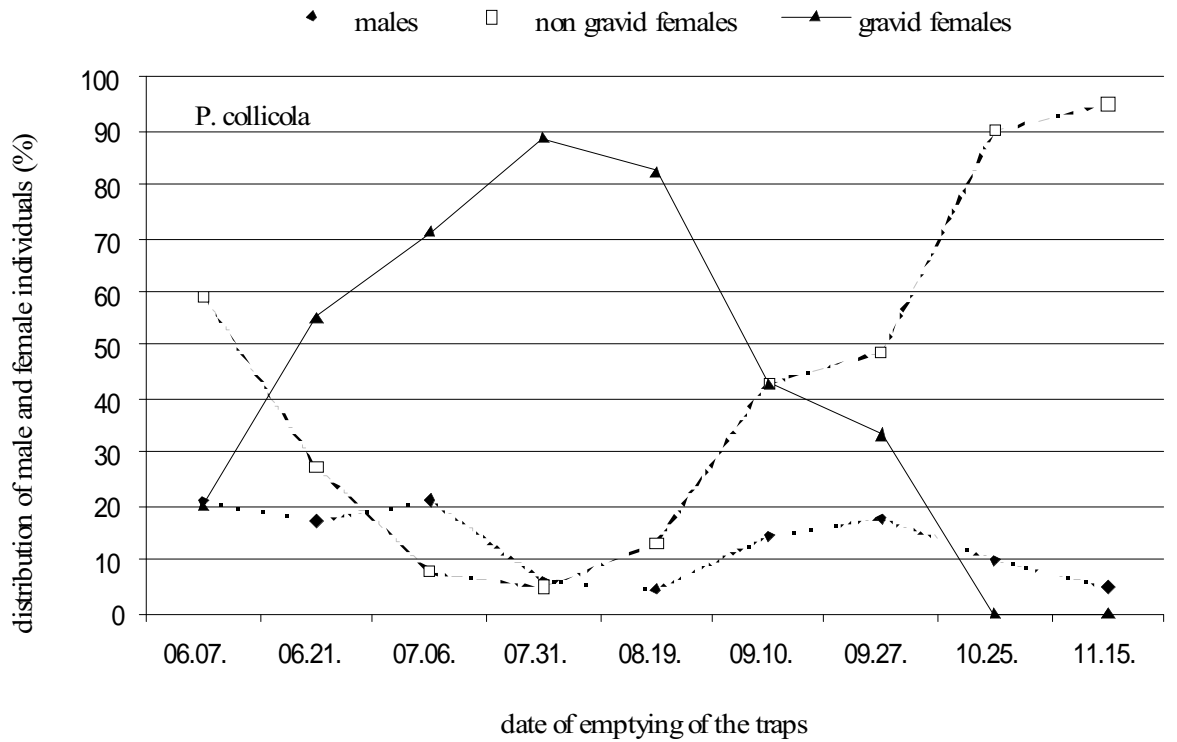

Fig. 7. Seasonal changes in the amount of male, gravid and non-gravid female individuals of $P$. collicola 


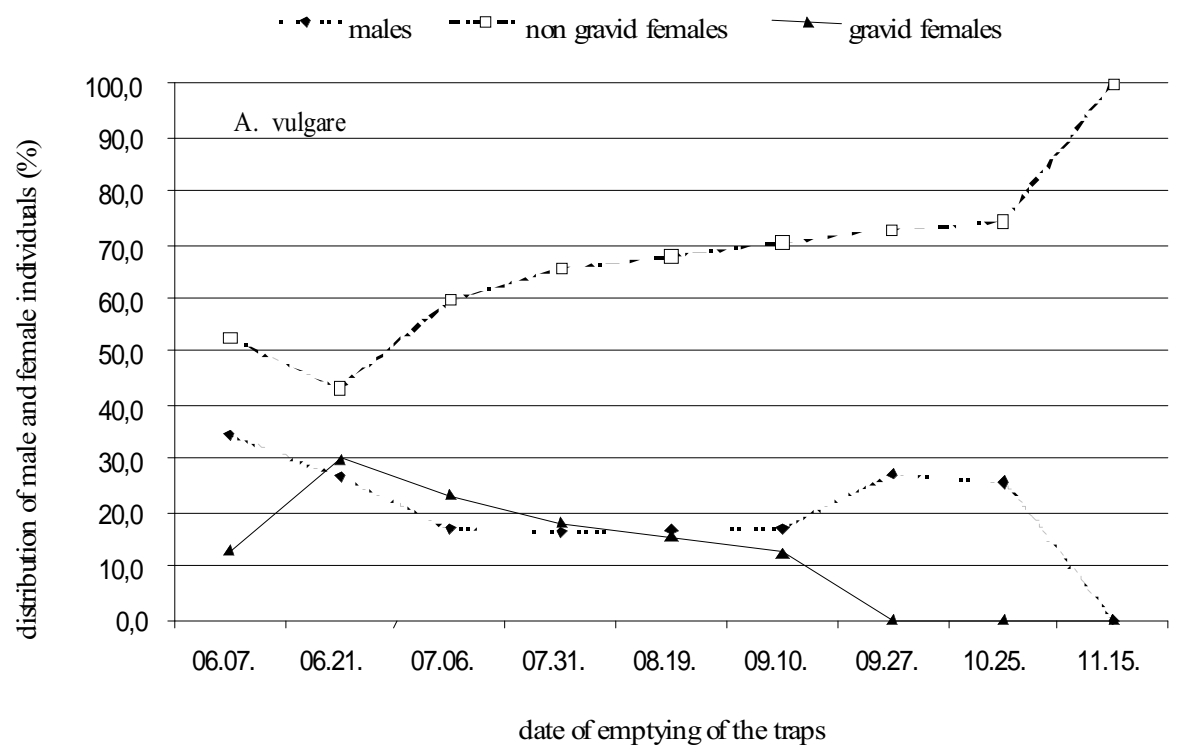

Fig. 8. Seasonal changes in the amount of male, gravid and non-gravid female individuals of $A$. vulgare

centage of the males ranged from 15 to 45. DANGERFIELD and HASSALL (1994) found the amount of male individuals of $A$. vulgare between $17-80 \%$. At Szilonicspuszta the participation of males for every species ranged from 10 to $50 \%$.

Comparing our results to other findings it can be concluded that probably the relatively high average temperature during the vegetation period and the appropiate humidity resulted in the outstandingly high number of individuals. In this ecological environment, under favorable temperature conditions plenty of juveniles can grow up. As we mentioned, in the habitats there was no observable leaf litter, so the reason the low proportion of gravid females (as had been expected) must be the lack of suitable food.

\section{Acknowledgments}

The research was sponsored by the Bolyai János Research Scholarship (BO/00304/01) of the Hungarian Academy of Sciences. Acknowledgments are due to Miss Mónika Szabadi and Sándor Bérces for technical assistance. 


\title{
References
}

DANGerfield, J.M. and Hassall M. 1994: Shelter site use and secondary sex ratios in the woodlice Armadillidium vulgare and Porcellio scaber (Crustacea: Isopoda) - J. Zool., Lond. 233, 1-7.

Dangerfield, J.M. and Telford S. R. 1994: Population size and sex ratios in some woodlice (Crustacea: Oniscidae) from southern Africa - J. Tropical Ecol. 10, 261-271.

FARKAS, S. 1998a: The terrestrial isopod fauna of the Rinya region II. Péterhida 1 - Misc. Zool.Hung. 12, 45-53.

FARKAS, S. 1998b: The Isopoda fauna of the Rinya region I. Bakháza (Hungary) - Somogyi Múzeumok Közl. XIII. 257-260.

FARKAS, S. 1999: Ecological Study on the Isopod Fauna by the Drava River. PhD Thesis - JATE, Szeged

GrunER, H. E. 1966: Krebstiere oder Crustacea. 5. Isopoda (Tierwelt Deutschlands. Gustav Fischer, Jena

Helden, A. J. and Hassall, M. 1998: Phenotypic plasticity in growth and development rates of Armadillidium vulgare (Isopoda: Oniscidea) - Israel J. Zool. 44, 379-394.

HoRnUNG, E. and WARBURG, M.R. 1993: Breeding patterns in the oniscid isopod, Porcellio ficulneus Verh., at high temperature and under different photophases. - Invertebrate Reproduction and Development. 23, 151-158.

MCQueEN, D. J. 1976: The influence of climatic factors on the demography of the terrestrial isopod Tracheoniscus rathkei Brandt - Can. J. Zool. 54, 2185-2199.

SNIDER, R. and SHADDY J. H. 1980: The ecobiology of Trachelipus rathkei (Isopoda) ( Pedobiologia 20, 394-410.

TótHмÉRÉsz, B. 1996: NuCoSA 1.05. Programcsomag botanikai, zoológiai és ökológiai vizsgálatokhoz Scientia Publishing, Budapest.

\section{The terrestrial isopod fauna of the Rinya region IV. Szilonics-puszta.}

\section{VADKERTI EDIT és FARKAS SÁNDOR}

1995 és 1998 között a Dráva-ártér 71 élıhelyén végeztünk kvalitatív-kvantitatív mintavételezést a terület szárazföldi ászkarák (Isopoda: Oniscidea) faunájának vizsgálata céljából. A mintahelyek egyikét Szilonics-pusztán jelöltük ki. Két, különböző vegetációval borított foltban (ártéri nyáros és aranyvesszıs ártéri gyom-vegetáció) összesen 10 talajcsapdát helyeztünk el line-transect elrendezésben. A folyamatosan mßködtetett csapdák 1996 júniusától novemberig összesen 21664 ászkarákot gyßjtöttek, melyek a következő 5 fajhoz tartoztak: Porcellium collicola Verh., Trachelipus ratzeburgi Brandt, T. rathkei Brandt, Armadillidium vulgare Latr. és Hyloniscus riparius Koch.. A két folt Isopoda együtteseinek összetételében nem találtunk különbséget. Mindkét foltban a $T$. ratzeburgi volt a domináns faj. A dolgozat további adatokat tartalmaz a gyßjtött fajok felszíni aktivitására és szaporodási jellemzıire vonatkozóan is.

\author{
Authors' addresses: \\ Edit VADKERTI \\ Department of Ecology and Zoogeography, \\ Biological Institute, Pécs University \\ H-7601 Pécs \\ HUNGARY \\ Sándor FARKAS Ph.D. \\ University of Kaposvár \\ Faculty of Animal Science \\ Institute of Cattle and Sheep Breeding \\ H-7400 Kaposvár \\ Guba S. 40. \\ HUNGARY
}

